\title{
Godronia multispora Groves (Helotiales) and Its Pathogenicity to Betula verrucosa Ehr. and B. pubescens Ehr.
}

\author{
Timo Kurkela \\ Finnish Forest Research Institute, Unioninkatu 40 A, \\ SF-00170 Helsinki, Finland
}

\begin{abstract}
A canker disease caused by Godronia multispora Groves on Betula verrucosa Ehr. and B. pubescens Ehr. was described. The disease occurred most frequently in drained peatlands. B. pubescens was more resistant to the disease than $B$. verrucosa.
\end{abstract}

\section{Introduction}

A formerly unknown disease was observed on young birch trees (Betula verrucosa Ehr. and B. pubescens Ehr) in the spring of 1964 at Kivisuo, an area with forest fertilization experiments set up by the Department of Peatland Forestry, Finnish Forest Research Institute. Kivisuo is situated in the parish of Leivonmäki in Central Finland. The present paper describes the disease and the fungus causing it as well as their occurrence and distribution in Finland.

On the young trees that suffered from the disease a fungus belonging to the genus Godronia was usually found. As Groves (1965), from the Plant Research Institute, Ottawa, Canada, had published a paper on the genus Godronia, samples of the infected trees were sent to him for more detailed examination. According to the identifications made by Groves, the fungus found on the samples was Godronia multispora Groves.

Prior to the publication of Groves's (1965) taxonomic study, the fungi of the genus Godronia appearing on birch were usually determined as belonging to the species $G$. urceolus (Alb. \& Schwein.) Karst. (e.g. Rehm 1896, 1912, Gash 1934, Seaver 1945,
Gremmen 1957, 1963). According to Groves (1965), at least two species have been referred to with this name, and as the first species description is dubious and as there exists no type specimen, the name $G$. urceolus (Alb. \& Schwein.) Karst. should not be used anymore. In his study of the genus Godronia Groves divided thie fungus into three different species occurring on birch, namely G. cassandrae Peck f. betulicola Groves, G. urceolus (Schmidt ex Fr.) Karst. and G. multispora Groves and into some other species which occur on Ribes.

The pathogenicity of Godronia fungi to birch has not been known for any long time. Smerlis $(1968,1969)$ indicated that $G$. cassandrae $\mathrm{f}$. betulicola may cause cankers on Betula alleghaniensis Brit., $B$. papyrifera Marsh. and B. populifolia Marsh. In Canada it has also been established that $G$. multispora occurs in association with cankers on $B$. papyrifera (Martineau and Lavallee 1971).

In Finland, Karsten (1871) has been the only one to publish something on the occurrence of Godronia fungi. According to Groves (1965), the question is about $G$. urceolus (Schmidt ex Fr.) Karst. In the collections of the Finnish Forest Research 


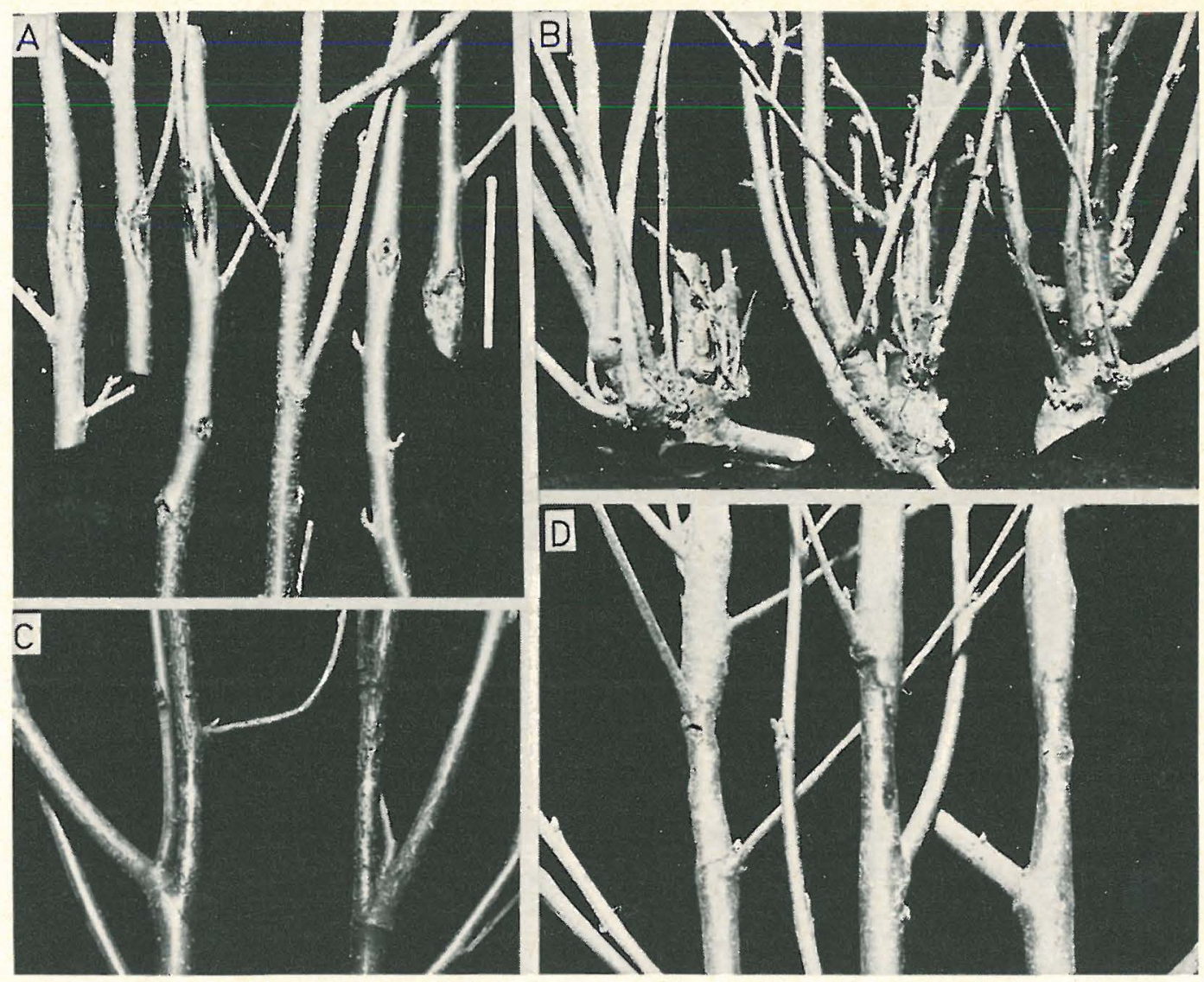

Fig. 1. Disease caused by Godronia multispora on young birch. A) Cankers on suckers of Betula verrucosa. B) Abundant sucker formation in B. verrucosa, the roots of which have been cut. Most of the suckers will die during their first winter. G-D) Suckers of B. pubescens that have been strangulated.

Institute there is a number of Godronia specimens collected by Prof. Viljo KujaLA, which have been partly examined by Groves (1965). None of the specimens examined, however, were representative of a species which uses birch as host.

\section{Material and Method of the Study}

The new disease which had been found on young birch trees was studied at its different stages of development from samples taken at Kivisuo. In order to establish the distribution of the disease samples were collected in various parts of the whole country. The morphology of the infected tissue and of the causal agent were studied from microtome sections. The sections were treated using the dying method presented by DRING (1955).
Hyphae of Godronia multispora were isolated from dead bark by transferring tissue aseptically onto agar. Monospore cultures were obtained both from conidia and from ascospores. The medium used was Hagem agar, which contained $5 \mathrm{~g}$ glucose, $5 \mathrm{~g}$ malt extract, $0.5 \mathrm{~g} \mathrm{KH}_{2} \mathrm{PO}_{4}, 0.5 \mathrm{~g} \mathrm{MgSO}_{4}, 0.5 \mathrm{~g}$ $\mathrm{NH}_{4} \mathrm{Cl}, 1 \mathrm{ml} \mathrm{FeCl}$ solution ( $1 \%$ ), $15 \mathrm{~g}$ agar, and $1000 \mathrm{ml}$ distilled water.

The pathogenicity of $G$. multispora was studied by inoculating hyphae from the cultures onto young birch trees. The inoculations were performed using the cork borer method described by WRIGHT (1933). Using a borer with a diameter of $4 \mathrm{~mm}$ a hole was made in the bark, which had been cleaned in advance with ethanol. Hyphae of the fungus were transferred into the hole from a culture in a petri dish, and then the 


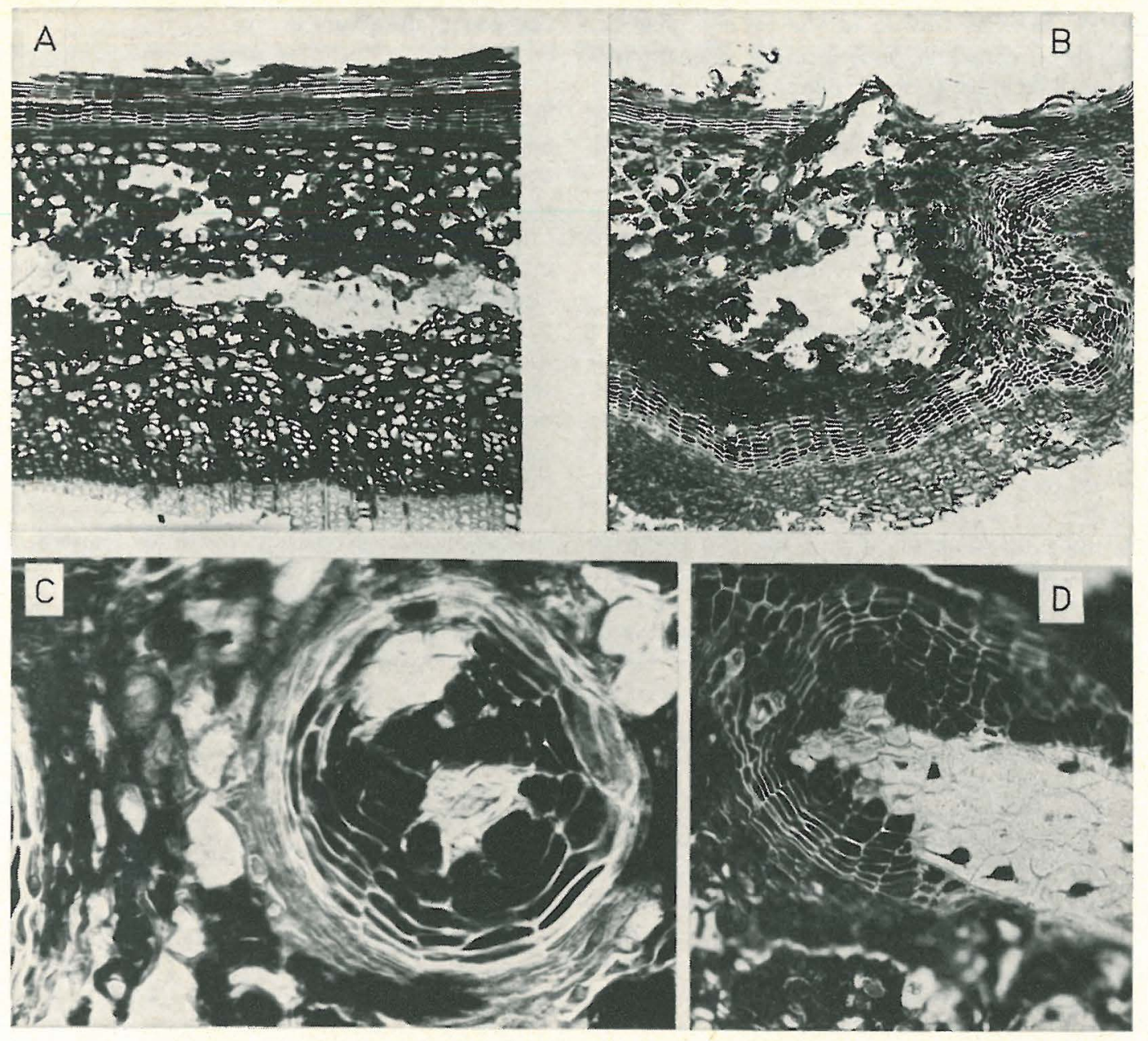

Fig. 2. Gross sections of bark of Betula verrucosa. A) Healthy bark of two-year-old sucker. B) Primary cork and secondary phellem at the edge of a canker. C-D) Cork rings that have formed around fiber cells in the tissue adjacent to a canker. A-B) $\times 50$, G - D) $\times 100$.

removed piece of bark was replaced and fastened tightly to the stem by means of cellophane tape.

All the pathogenicity tests were performed on healthy young trees of Betula verrucosa and $B$. pubescens growing on mineral soil. At the inoculation points the stem diameter varied between 1 and $3 \mathrm{~cm}$.

The temperature requirements of $\mathrm{G}$. multispora were studied by germinating its Topospora conidia on $5 \%$ water agar and cultivating the fungus at temperatures of 5 , $10,15,20,25$, and $30^{\circ} \mathrm{C}$. After 15 days' incubation the radius of the colonies (that had developed) in the petri dishes were measured. In the germination experiments the conidia were considered as having germinated when a swelling was observed which differed in shape from the normal shape of the spore and which had a width at least equalling that of the spore.

\section{Description of the Disease}

\section{Symptoms}

In the Kivisuo area, where the development of the disease was studied in detail, cankers occurred on young trees both of Betula verrucosa and of $B$. pubescens (Fig. 1). In springtime suckers that had died at the age of $1-2$ years were found in abundance; they had probably been infected after the cessation 
of the growing season of the preceding year. In some cases the extension of the cankers continued during the growing season, leading to strangulation and wilting of the young trees. In nature the infection seemed usually to have taken place through mechanical injuries on the periderm or through buds. In many cases the primary infection had taken place in small branches, from which necrosis then had spread to the stem. In unfertilized and in slightly fertilized sample plots stunted young trees occurred in abundance, and where this was the situation most of the oneyear-old suckers died during their first dormancy season (Fig. 1). The root collar of these trees could be even as much as $10 \mathrm{~cm}$ below the upper surface of the moss layer. Usually no damages were found on the part of the stem which was imbedded in the moss vegetation or on the root systems.

The widening of the cankers was largest in the period of dormancy of the birch. During the growing season the trees tried to prevent the disease from spreading in the bark by producing secondary phellem around the dead tissue (Fig. 2). A pathologic secondary cork cambium can be formed out of almost any primary bark tissue apart from stone cells and fibers. In conjunction with the formation of secondary phellem a hypertrophic thickening of the bark occurred which was due to the fact that the secondary cork cambium produced cork cells outwards and phelloderm cells inwards (Fig. 2). It has been established that the primary cork cambium of healthy bark almost solely produces cork cells outward (cf. Holdheide 1951, FREMER 1967). In the nearest surroundings of the necrotic tissue the bark fibers occuring in tissue which was still alive could become encased by cork tissue; this phenomenon could be seen in the cross section in the form of detached cork rings around fibers (Fig. 2). There is the possibility that these fiber cells have been in direct contact with the dead tissue, and that this would be the reason for the formation. Sorauer (1907) found that similar cork rings form around the fibers in conjunction with frost cracks in wood.

From the young cankers Topospora pycnidia of G. multispora (Fig. 3) were found in the late fall and in the spring. In old cankers and on dead suckers apothecia of $G$. multispora developed during the late summer (Fig. 3).

\section{Godronia multispora}

\section{Perfect State}

The apothecia of Godronia multispora emerged from under the cork tissue of birch trees. Sometimes apothecia were found growing on suckers from which the bark had fallen off. The apothecia had a width of $0.5-1 \mathrm{~mm}$, and they were usually sessile. During dry spells the edges of the apothecia were folded inward, but when they got wet, they opened taking a cupular or urceolate shape (Fig. 3). The apothecia were reddish brown to black and slightly furfuraceous or longitudinally striate. They were either separate or caespitose. With regard to their external features the apothecia now examined corresponded completely to those described by Groves (1965), and this was also true for their internal structure, which was studied from microtome slides (Fig. 3).

The asci were cylindrical of slightly clavate. The size of the asci that were measured (Table 1) was in full accordance with the figures presented by Groves (1965). The ascospores of this fungus were long and narrow and septate (Fig. 3). Their length was $60-80 \mu$ and their width $2-3 \mu$.

According to Groves (1965) the ascospores of $G$. multispora divide into short cylindrical or elliptical cells with a size of $5-9 \times 2-$ $3 \mu$. These, in turn, develop into conidia. From the samples examined in conjunction with the present study multispored asci of the kind described by Groves (1965) were found. Likewise, a type of formation of conidia from ascospores differing from that described was observed. The conidia, which had formed from ascospores either inside or outside the asci, had a size of $2-5 \times 1-2 \mu$. In the case of some samples the primary ascospores had grown out from the apex of the asci by producing conidiophores and conidia of the kind mentioned from two or three of their apical cells (Figs. 3 and 4). When the formation of conidia now continued, it seemed that the walls of the asci gradually disappeared, the spores remaining attached to the hymenium as branched bundles. Besides from the apical cells and from basal cells tormed from them, conidia could also be formed from the central cells of the ascospores. The first basal cell usually developed at the apical cell of the ascospore. This basal cell, in turn, was capable of forming a conidium, and in 


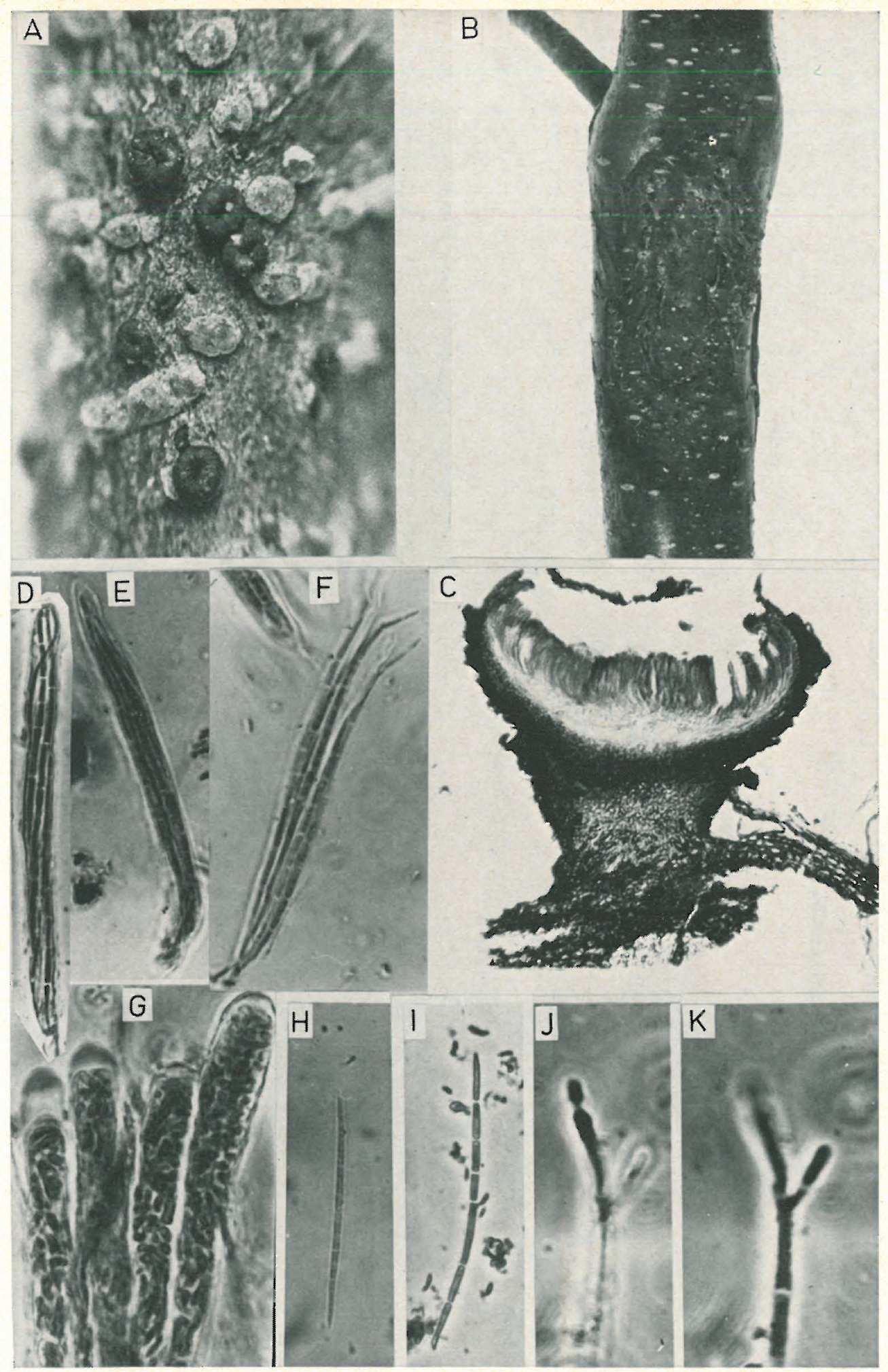

Fig. 3. Godronia multispora. A) Apothecia on the bark of a sucker of Betula verrucosa. The light formations are pitch glands. B) Canker on the stem of B. pubescens with erumpent Topospora pycnidia. G) Section of apothecium. D-G) Asci. F) Partly broken up ascus, in which conidiophores have formed from the apical cells of the ascospores. G) Multispored asci, filled with microconidia. $\mathrm{H}-\mathrm{I}$ ) Ascospores. J-K) Tip of ascospore with a conidiophore and cnidia. A) $\times 10$, B $\times(.5$, C) $\times 50, D-F) \times 500$, G) $\times 600, \mathrm{H}) \times 300$, I $) \times 500$, $\mathrm{J}-\mathrm{K}) \times 1000$. 
Table 1. Size of the asci of Godronia multispora as measured from samples collected from four localities.

\begin{tabular}{|c|c|c|c|c|c|c|c|c|c|c|c|c|c|c|c|c|c|}
\hline $\begin{array}{l}\text { Length } \\
\text { of asci, } \mu\end{array}$ & 60 & 65 & 70 & 75 & 80 & 85 & 90 & 95 & 100 & 105 & 110 & 115 & 120 & 125 & 130 & 135 & 140 \\
\hline Locality & \multicolumn{17}{|c|}{ Frequency, \% } \\
\hline $\begin{array}{l}\text { Leivon- } \\
\text { mäki } \\
\text { Muhos } \\
\text { Pudasjärvi } \\
\text { Kemi }\end{array}$ & & 1 & 2 & 6 & $\begin{array}{l}1 \\
1 \\
9\end{array}$ & $\begin{array}{l}2 \\
3 \\
7\end{array}$ & $\begin{array}{r}4 \\
13\end{array}$ & $\begin{array}{r}8 \\
10 \\
11 \\
2\end{array}$ & $\begin{array}{r}29 \\
13 \\
8 \\
2\end{array}$ & $\begin{array}{r}50 \\
11 \\
14 \\
5\end{array}$ & $\begin{array}{r}4 \\
16 \\
5 \\
7\end{array}$ & $\begin{array}{r}2 \\
18 \\
4 \\
20\end{array}$ & $\begin{array}{r}14 \\
3 \\
20\end{array}$ & $\begin{array}{r}8 \\
2 \\
21\end{array}$ & $\begin{array}{r}5 \\
16\end{array}$ & $\begin{array}{l}1 \\
5\end{array}$ & 2 \\
\hline $\begin{array}{l}\text { Width } \\
\text { of asci, } \mu\end{array}$ & 6.0 & 6.5 & 7.0 & 7.5 & 8.0 & 8.5 & 9.0 & 9.5 & 10.0 & 10.5 & 11.0 & 11.5 & 12.0 & 12.5 & 13.0 & 13.5 & 14.0 \\
\hline Locality & \multicolumn{17}{|c|}{ Frequency, \% } \\
\hline $\begin{array}{l}\text { Leivon- } \\
\text { mäki } \\
\text { Muhos } \\
\text { Pudasjärvi } \\
\text { Kemi }\end{array}$ & $\begin{array}{l}3 \\
6 \\
6\end{array}$ & $\begin{array}{l}8 \\
4 \\
6 \\
9\end{array}$ & $\begin{array}{r}16 \\
3 \\
15 \\
26\end{array}$ & $\begin{array}{r}13 \\
4 \\
21 \\
23\end{array}$ & $\begin{array}{l}20 \\
10 \\
20 \\
17\end{array}$ & $\begin{array}{r}12 \\
8 \\
12 \\
15\end{array}$ & $\begin{array}{r}9 \\
5 \\
12 \\
2\end{array}$ & $\begin{array}{r}10 \\
11 \\
6 \\
2\end{array}$ & $\begin{array}{r}7 \\
15 \\
2\end{array}$ & $\begin{array}{l}2 \\
7\end{array}$ & 10 & 10 & 8 & 2 & 2 & 1 & \\
\hline
\end{tabular}

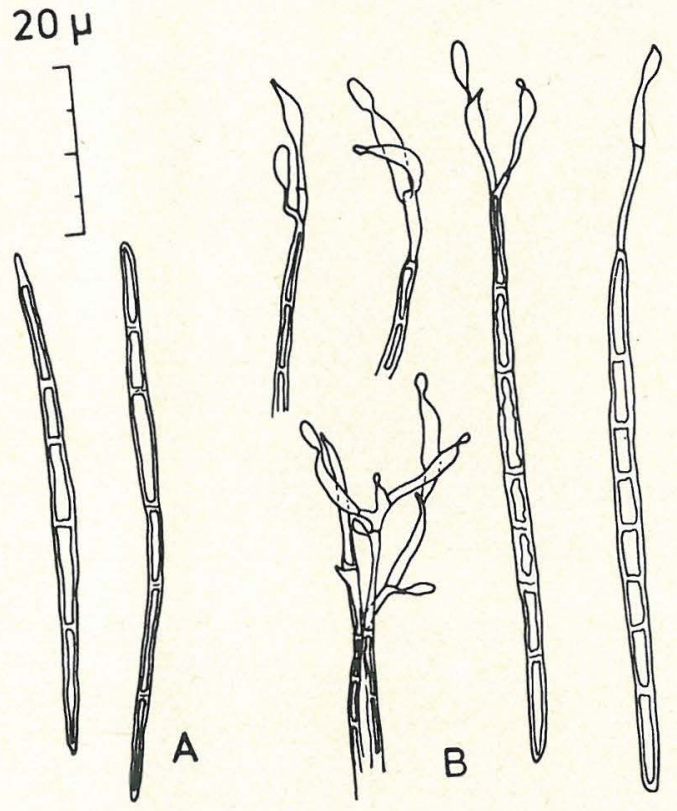

Fig. 4. Godronia multispora. A) Ascospores. B) Ascospores forming microconidia.

most instances, one or more secondary basal cells. In this way a branched conidiophore gradually developed at the tip of the spore (Fig. 4). The size of the basal cells was 5 $15 \times 2-4 \mu$, and they were often slightly swollen at the tip. The formation of basal cells caused inaccuracy to the measurement of the length of ascospores.
A formation of conidia from ascospores has not been established in the case of other Godronia species (cf. Schläpfer-Bernhard 1968, ERIKSSON 1970). In many fungi belonging to the family Geoglossaceae, on the other hand, such formation of conidia is a generally known phenomenon (MaIns 1955, 1956, Geitler 1958, Berthet 1969).

The perfect state of Godronia multispora (apothecia) was found in nature during the late summer and fall. In particular the samples collected in september had ascospores forming conidia.

\section{Conidial states}

The pycnidia of Godronia multispora had a width of $0.5-1.5 \mu$, growing erumpent from under the cork tissue of the bark (Figs. 3 and 5). They were black and often glossy. The central parts of the pycnidia were hyaline and one- or two-chambered. Macroconidia were formed in branched, septate conidiophores, the length of which was $20-50 \mu$. The conidia, which usually had one septum, were hyaline and had a fusiform to elliptical shape (Figs. 5 and 6). The size of the conidia was (2.0) $3.0-4.5$ (5.5) $\times(8.0) 11.0-16.0$ (18.0) $\mu$.

The fungus (also the monospore cultures with ascospores) produced conidia-forming pycnidia about three months after transfer on Hagem agar. The size of the conidia of the pure cultures did not differ to any sigificant extent from that of natural conidia 


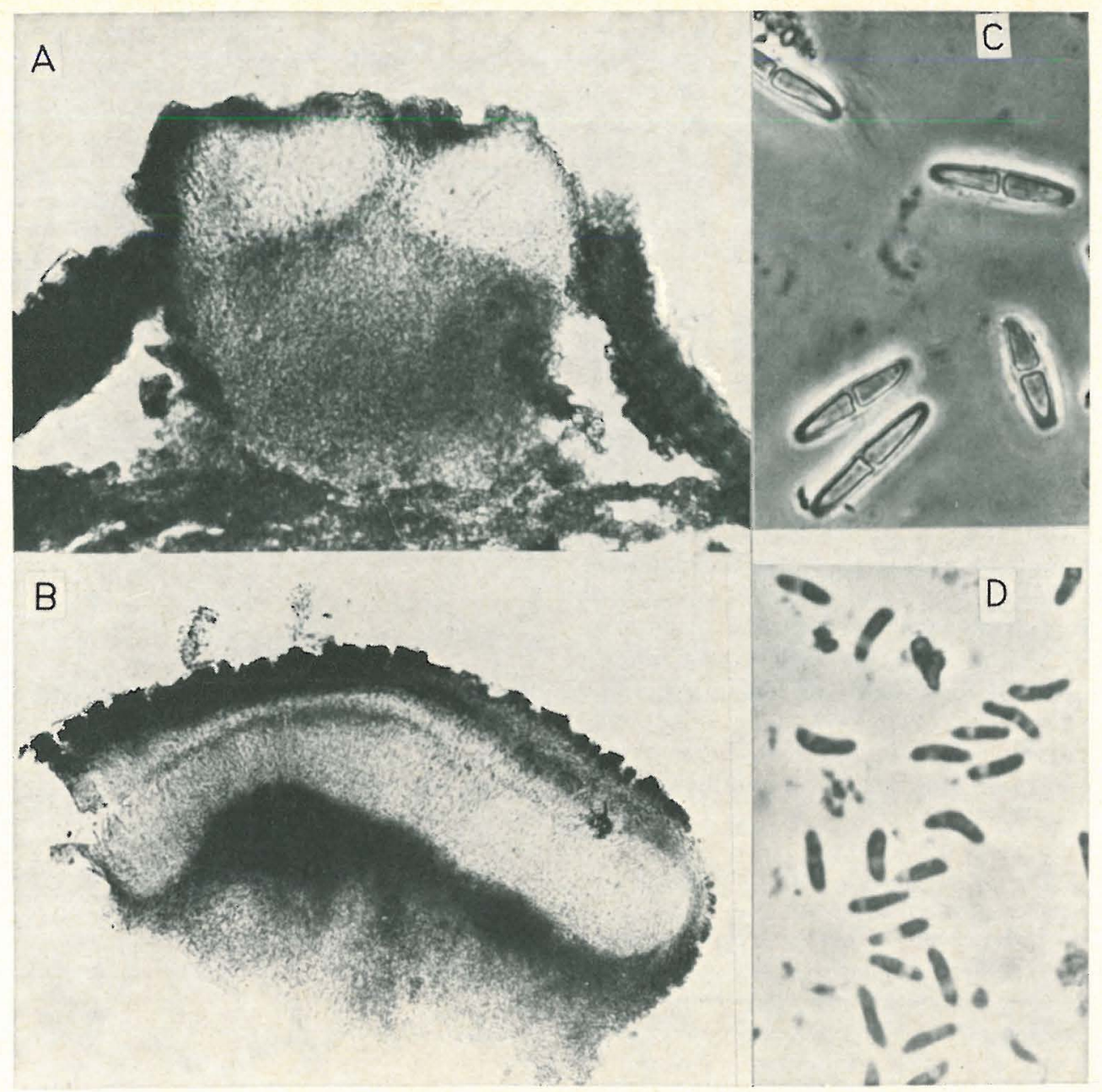

Fig. 5. Godronia multispora. A-B) Section of Topospora pycnidium. C) Conidia from Topospora pycnidium. D) Microconidia. A-B) $\times 50$, C-D) $\times 1000$.
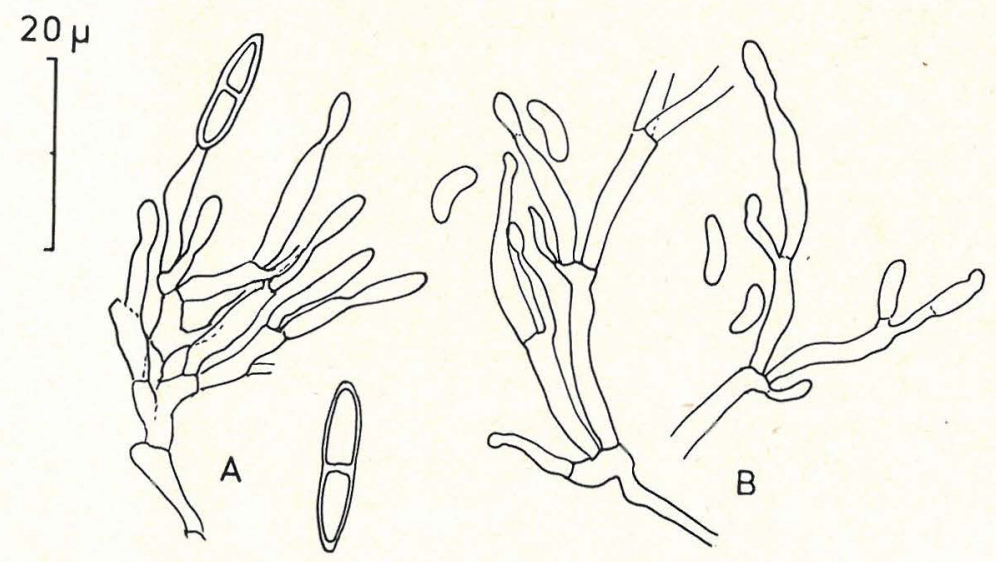

Fig. 6. Godronia multispora. A) Conidiophore and two conidia from Topospora pycnidium. B) Microconidia and conidiophores. 
and the slight differences occurring between individual samples might have been due to the fact that those which had been collected from nature were not all representative of exactly the same stage of development.

According to Groves (1965) the macroconidia-forming pycnidia of the genus Godronia belong to the imperfect genus Topospora Fr.

There is also a conidial state in G. multispora during which microconidia are formed. The formation of conidia from ascospores can be considered as one of its form of manifestation. Conidiophores with a structure similar to those formed from ascospores were frequently found during the period June-July; they occurred as bundles on the hymenium of apothecia under development. The microconidia formed corresponded both in size and shape to those formed from ascospores. They were one-celled and slightly curved, and most of them had a somewhat irregular form (Figs. 5 and 6). The inner part of microconidia that had been treated with safranin was not evenly stained.

\section{Effect of temperature on the growth}

Fig. 7 shows the effect of temperature on the germination of macroconidia of Godronia multispora. Six hours after the beginning of the experiment no signs of germination could be observed at any temperature covered by the experiment. The first germinated conidia were observed twelve hours from the start of the experiment. Germination was fastest at temperatures of $20-25^{\circ} \mathrm{C}$. After 24 , and especially after 48 hours, the differences between the numbers of germinated conidia at different temperatures had leveled out, being $100 \%$ in almost all cases. Only in the case of a temperature of $5^{\circ} \mathrm{C}$ was the percentage germinated conidia about $80 \% 48$ hours from the beginning of the experiment.

The fastest germ tube growth was recorded for the temperature of $20^{\circ} \mathrm{C}$. At $15^{\circ}$ the growth was faster than at $25^{\circ}$ (Fig. 7).

A temperature of $15^{\circ} \mathrm{C}$ seemed to be best for the growth of the hyphae of the fungus in petri dishes (Fig. 7). At $30^{\circ}$ no growth was recorded. At low temperatures the growth was rather strong, and the hyphae could be observed to grow still at temperatures as low as $2-3^{\circ} \mathrm{C}$.
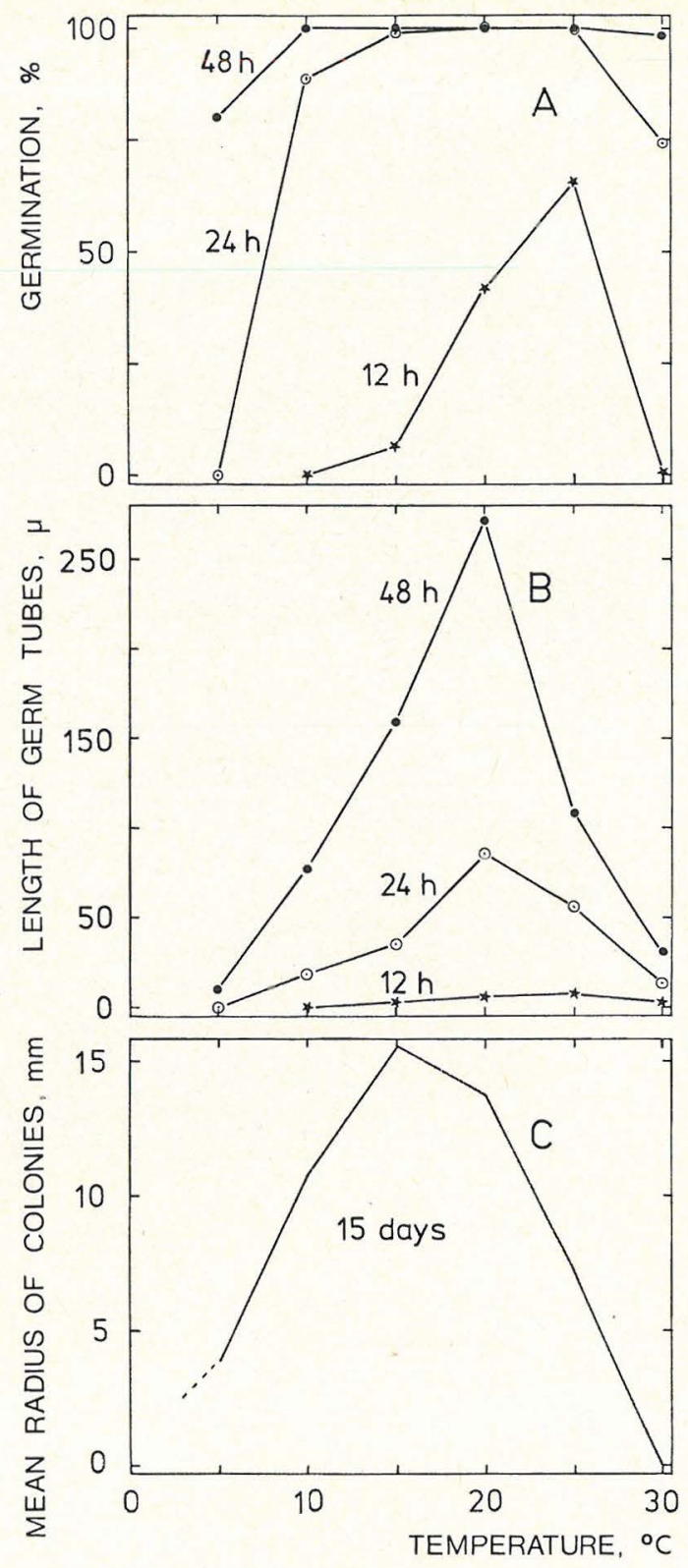

Fig. 7. Effect of temperature on the growth of Godronia multispora on agar. A) Germination of Topospora conidia. B) Growth of germ tube. G) Growth of hyphae.

\section{Pathogenicity}

The pathogenicity tests carried out with the hyphae of Godronia multispora led to positive results in cases when the inoculation had been performed in October or April into wounds caused to the bark. Inoculations which were performed in July and August 

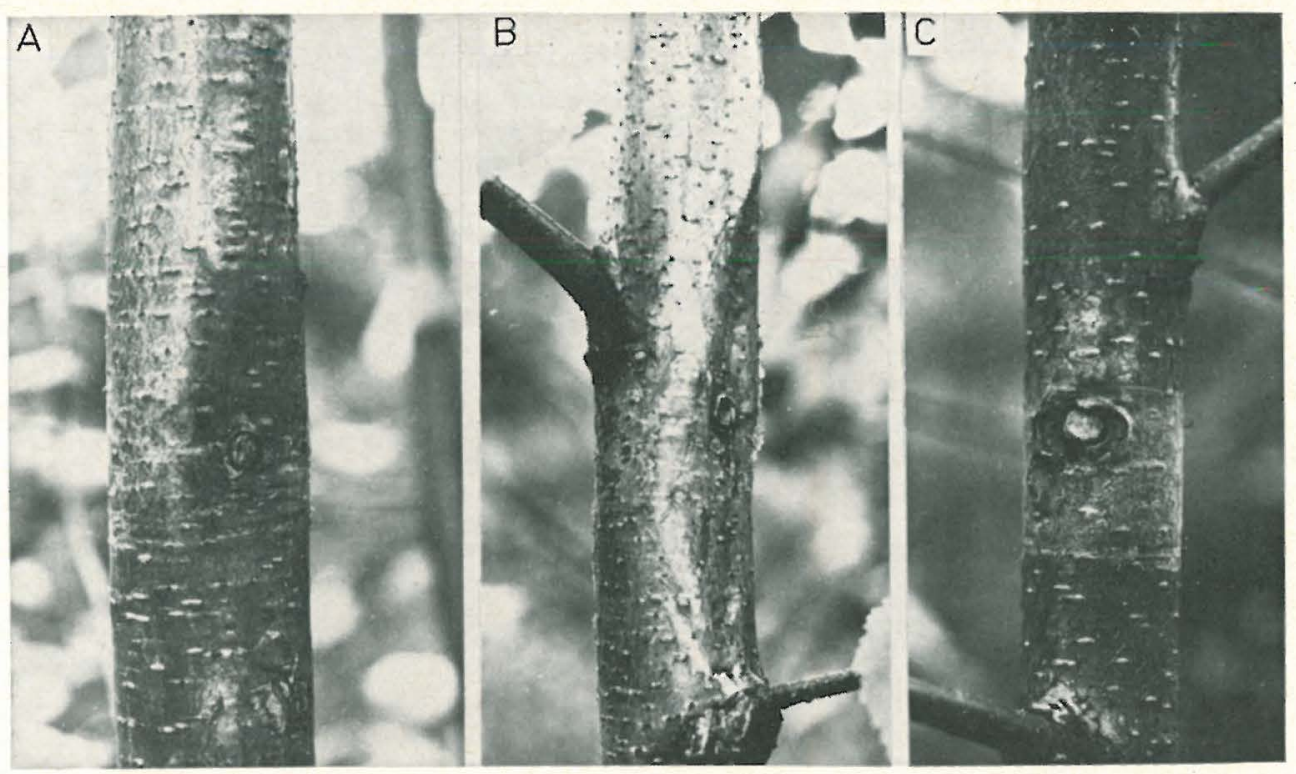

Fig. 8. Results from inoculation experiments. A-B) Inoculation with hyphae of Godronia multispora. No radial growth has occurred around the point of infection. C) Control. The point of inoculation has become considerably overgrown.

gave altogether negative results. This was also the situation in the case of the controls; here the inoculations were performed either using hyphae of Godronia on intact bark or using sterile agar on wounded bark.

Fig. 8 shows necrosis in Betula verrucosa, caused by spreading of the infection from the inoculation wound. The inoculations in question were performed in the early April 1967, and the results were measured and photographed in the fall of the same year. In all places which were inoculated with the hyphae of $G$. multispora, necrosis occurred, whereas all the wounds which were used for the control were overgrown to an advanced degree already in the next September. The average size of the cankers covered by the experiment (20 inoculations) was $40.5 \times 14.5$ $\mathrm{mm}$ in the case of Betula verrucosa and $22.8 \times 12.0 \mathrm{~mm}$ in the case of $B$. pubescens. The experiment was repeated on April 3 the following year, with similar results (Table 2). Necrotic tissue became distinguishable after one or two months, when diameter growth had initiated. Necrosis did not extend during the growing season. The extention of the cankers during the following two dormancy periods was of no great importance either, and they began gradually to become overgrown. The resistance reactions of the young
Table 2. Size (in $\mathrm{mm}$ ) of cankers on Betula verrucosa and $B$. pubescens in the pathogenicity test with Godronia multispora. The trees were inoculated April 3, 1968 and cankers measured June 28, 1968 and April 28, 1970.

\begin{tabular}{|c|c|c|c|c|c|}
\hline \multirow[t]{2}{*}{ Host } & \multirow[t]{2}{*}{$\begin{array}{l}\text { Group of } \\
\text { trees }\end{array}$} & \multicolumn{4}{|c|}{$\begin{array}{l}\text { Date of measurement } \\
\text { June } 1968 \quad \text { April } 1970\end{array}$} \\
\hline & & $\begin{array}{l}\vec{c} \\
\text { की } \\
\vec{d} \\
\sim\end{array}$ & 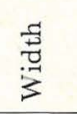 & 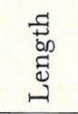 & 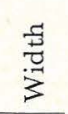 \\
\hline Betula verrucosa & I & 30.0 & 14.4 & 35.8 & 18.7 \\
\hline$\gg$ & II & 38.8 & 21.4 & 39.3 & 18.2 \\
\hline$\gg$ & III & 50.0 & 14.8 & 47.8 & 15.7 \\
\hline$\gg$ & $\bar{x}$ & 39.6 & 16.9 & 41.0 & 17.5 \\
\hline B. pubescens & I & 21.0 & 13.6 & 23.0 & 16.6 \\
\hline$\gg$ & II & 18.2 & & 15.8 & 18.8 \\
\hline$\gg$ & III & 24.6 & 13 & 23.5 & 16.7 \\
\hline$\gg$ & $\overline{\mathrm{x}}$ & 21.3 & 13.1 & 20.9 & 17.4 \\
\hline
\end{tabular}

I-III) Five replications in every tree group $\mathrm{x}$ ) Mean of the tree groups

birch trees used in the exeriments were thus evidently strong enough to stop further spreading of the fungus. Nevertheless, as late as two years after the inoculations Topospora pycnidia of $G$. multispora were still found from the cankers, and it was possible at that time to isolate the fungus both from the cankers and from the dead tissue. 
Susceptibility of Betula verrucosa and B. pubescens

In the experimental area at Kivisuo as well as in a drained peatland area in the southern part of the province of Häme, the Aittoniemensuo in Loppi, the condition of young trees both of Betula verrucosa and of $B$. pubescens was examined. B. verrucosa showed to be clearly more susceptible to the disease caused by Godronia multispora than $B$. pubescens. The results of the inventory performed are presented in Table 3 .

Table 3. Occurrence of the disease in the young birch trees (Betula verrucosa and B. pubescens) examined at Kivisuo (Leivonmäki) and Aittoniemensuo (Loppi).

\begin{tabular}{|c|c|c|c|c|}
\hline \multirow[t]{2}{*}{ Location } & \multicolumn{2}{|c|}{ Betula verrucosa } & \multicolumn{2}{|c|}{ B. pubescens } \\
\hline & 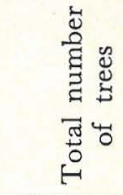 & 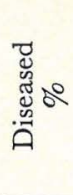 & 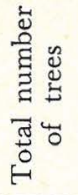 & 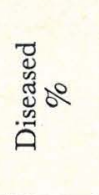 \\
\hline Kivisuo I & 5843 & 34 & 5424 & 5 \\
\hline Kivisuo XI & 3952 & 47 & 2350 & 25 \\
\hline Loppi & 174 & 53 & 433 & 4 \\
\hline
\end{tabular}

In the pathogenicity tests the cankers formed were appreciably greater in $B$. verrucosa than in $B$. pubescens. The latter species seems consequently to be capable to inhibit more efficiently than the former the spreading of the pathogen into the tissue surrounding the inoculation point.

\section{Occurrence and Distribution of the Disease and of Grodronia multispora}

The disease which has been described in the present paper and the fungus associated with it, Godronia multispora, seem to be of frequent occurence in young birch stands growing on peat. The commonest habitats of the disease seemed to be drained peatlands and the paludified edges of mineral land areas. Particularly in northern Finland, $G$. multispora was also found on stunted young birches on poor sandy soils. A few samples of birch seedlings suffering from the disease and of Godronia multispora have also been found from nurseries. The type specimens of G. multispora collected in Canada come from black spruce bog (Groves 1965).
The range of Godronia multispora is of course rather poorly known. In Canada the fungus has been found from Ontario (Groves 1965) and from Quebec (Martineau and Lavalle 1971). In Europe there is one specimen from Germany and one from Latvia (USSR) (Groves 1965). In Finland, according to the material presented in this paper, $G$. multispora seems to be fairly common (Fig. 9). As mentioned in the foregoing,

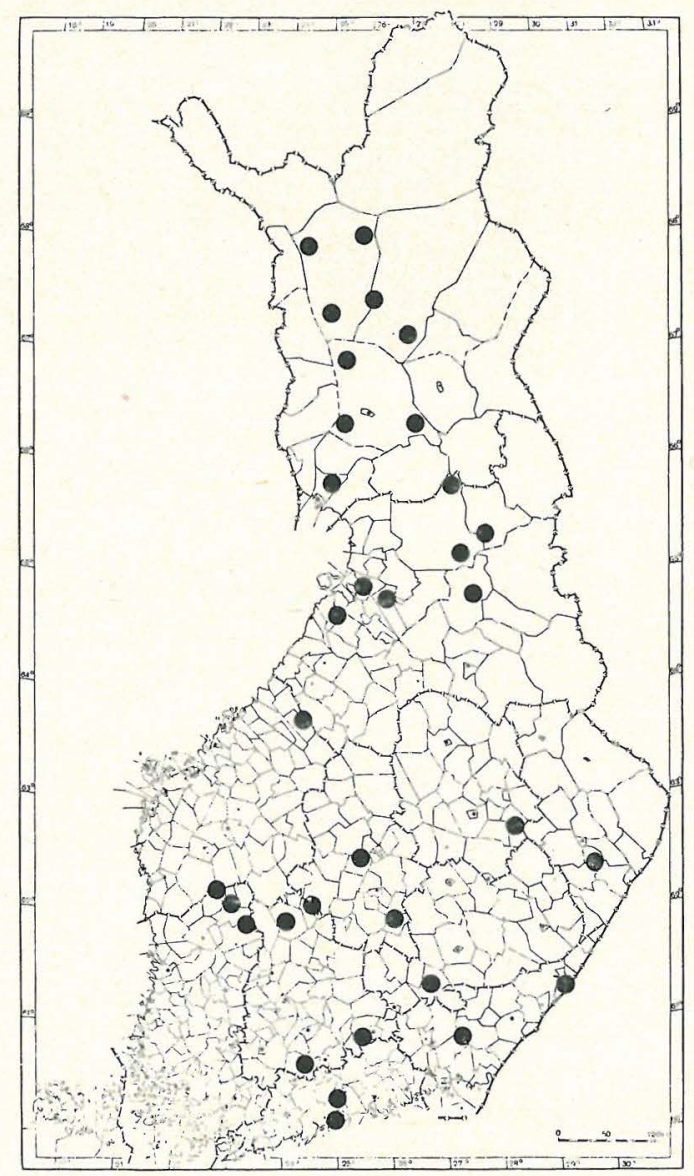

Fig. 9. Distribution of Godronia multispora in association with a canker disease of birch.

its occurrence is limited, however, primarily to peatlands and paludified mineral soils.

\section{Discussion}

The study showed that Godronia multispora is common in young birch stands growing on peat and paludified mineral sols. The inoculation experiments carried out with the 
hyphae of the fungus indicated its pathogenicity. The infection following inoculation led to necrosis, although this was the case only during the dormancy period of the birch in the fall and early spring. Evidently the capacity of birch to inhibit spreading of the hyphae of Godronia that have entered the bark tissue is rather poor except during the growing season, when the trees are active. The results obtained from the inoculation tests corresponded well to those obtained in the case of other Godronia species (SMerLis 1968, Weingartner and KLos 1969). The fact that an infection could be brought about merely by breaking the bark of healthy trees is probably an indication that mechanical resistance is an important factor in the fight against the disease in the bark of birch. Snow may be of importance for the spreading of G. multispora to suckers of birch. With its weight snow may cause mechanical damage to buds and break the branches at their base. In the spring the alternating freezing and melting of water and ice may also be a source of necrosis at the base of young trees (cf. EIche 1966), and in such cases it is possible that Godronia can complete the damage. Infection may also take place through leaf scars.

The results obtained from the pathogenicity tests and the cultivation of hyphae indicated that Godronia multispora thrives at relatively low temperatures (see pp. 10-12). With regard to its temperature amplitude the species is comparable to Phacidium infestans Karst. (cf. Björkman 1948). G. cassandrae Peck, which is pathogenic to cultivated cranberry, grew best at a temperature of $20^{\circ} \mathrm{C}$, but a weak growth was recorded even at $0^{\circ} \mathrm{C}$ (Shear, Stevens, and Bain 1931). In the experiments performed by SCHLÄPFER-BERNHARD (1968), the optimum temperatures with regard to the growth of hyphae of Godronia species were 18 and $21^{\circ} \mathrm{C}$.

In the identifications of the pathogen performed in conjunction with the present study from samples taken from nature, only Godronia multispora was found. It is possible, however, that two more species occur on young birches in Finland, namely $G$. cassandrae f. betulicola and $G$. urceolus, the former of which has established itself as a pathogen in Canada, according to studies performed by SMERLIS $(1968,1969)$.

It was established that Godronia multispora causes the disease both to Betula verrucosa and to $B$. pubescens. With regard to the symptoms of the disease, no differences could be observed between the tree species in question. B. pubescens, however, was clearly more resistant to the pathogen than $B$. verrucosa. This difference in the susceptibility to the disease was established both through the pathogenicity experiments conducted and in the occurrence of the disease on drained peat. The difference in the capacity of the tree species in question to resist the disease is probably due to differences in their requirements on the site, and particularly, on its nutritional conditions (cf. GunNars SON 1925, Kujala 1946, 1964; Sarvas 1949). Betula verrucosa is primarily known as a species growing on mineral soils, whereas $B$. pubescens is common also on peat. SARvaS (1948) established that seedlings of $B$. verrucosa appear on peaty sites, too, but in smaller numbers than those of $B$. pubescens, when comparing the numbers of seedlings occurring with the seed yields of the tree species in question. On peaty substrates in a natural state the seedling of $B$. verrucosa are probably destroyed at a rather early stage, as the birch stands occurring on peat are usually formed by $B$. pubescens alone. Godronia multispora and the disease caused by the fungus may be considered as one of the reasons for the destruction of Betula verrucosa seedlings growing on peat. In the case of the birch stands growing in the Kivisuo area Godronia multispora seemed to be one of the most important agents causing death to the young trees. Quite probadly the nuttional status of peat soils, which did not meet the requirements of $B$. verrucosa, led to such a weakening of the seedlings that infection by the pathogen became possible (cf. Kurkela 1973).

\section{Summary}

Godronia multispora Groves (Helotiales) was found to occur on young birch trees (Betula verrucosa and $B$. pubescens) in various parts of Finland. Most frequently the fungus was found in young birch stands growing on peaty substrates or in paludified areas. Inoculations carried out with the hyphae of the fungus caused necrosis to the bark tissue of birches. Necrosis took place mainly during the dormancy period of the trees. The patho- 
genicity tests performed indicated that $B$. pubescens is more resistant to the disease than $B$. verrucosa. In nature the disease was clearly more common in $B$. verrucosa than in $B$. pubescens.

A resistance reaction of the trees was the formation of secondary phellem around the infected tissue.

Topospora pycnidia of Godronia multispora were usually found in springtime from infected young birches. In the initials of the ascocarps that form during the summer, development of microconidia was found to take place. Similar microconidia are also formed in the fall from the ascospores of fully devel- oped ascocarps. Germination of the Topospora pycnidia was fastest at a temperature of $25^{\circ} \mathrm{C}$. For the growth of germ tube and hyphae the optimum temperatures were $20^{\circ} \mathrm{C}$ and $15^{\circ} \mathrm{C}$ respectively.

\section{Acknowledgements}

Dr. Olavi Huikari, head of the Department of Peatland Forestry, Finnish Forest Research Institute, made this investigation possible by allowing the use of the field experiments of the Department. For this the author wishes to thank him. The author is also indebted to Mrs. Inkeri Erjala and Mr. Simo Leinonen for technical assistance and to Mr. Karl-Johan Ahlsved for translation of the manuscript.

\section{REFERENGES}

Berthet, P. 1969: Présence de conidies d'origine sporale dans les asques de Spathularia flavida Pers. ex Fr. - Trav. Lab. »La Jaysinia» 3: 85-87.

BJörkman, E. 1948: Studier över snöskyttesvampens (Phacidium infestans Karst.) biologi samt metoder för snöskyttets bekämpande. - Medd. Stat. Skogsforskningsinst. 37,2. $136 \mathrm{pp}$.

CASH, E. K. 1934: Godronia urceolus and other Cenangiaceae on Ribes. - Mycologia 26: $266-272$.

Dring, M. D. 1955: A periodic acid-Schiff technique for staining fungi in higher plants. New Phytologist 54: 277-279.

Erche, V. 1966: Cold damage and plant mortality in experimental provenance plantations with Scots pine in northern Sweden. - Stud. For. Suec. 36. 219 pp.

Eriksson, B. 1970: On Ascomycetes on Diapensiales and Ericales in Fennoscandia. 1. Discomycetes. - Symb. Bot. Upsaliensis 19,4. 71 pp.

Fremer, K.-E. 1967: Kuoren anatominen rakenne ja kemiallinen koostumus. - In W. JENSEN (ed). Puukemia. pp. B7, 1-18. Tekn. Tiet. Akatemia, Helsinki.

Geitler, L. 1958: Konidienbildung aus Ascosporen bei Geoglossaceen. - Oesterr. Bot. Zeitschr. 105: 159-166.

Gremmen, J. 1957: Some Discomycetes from Norway with special reference to Codronia urceolus (A. \& S.) Karst. - Nytt Mag. Bot. 6: $11-18$.

$\longrightarrow$ - 1963: Preliminary notes on Godronia and association with conidial fungi. - Nova Hedwigia 6: 15-20.

Groves, J. W. 1965: The genus Godronia. Can. J. Bot. 43: 1195-1277.

Gunnarsson, J. G. 1925: Monografi över Scandinaviens Betulae. - Malmö. 136 pp.

HoldHeide, W. 1951: Anatomie mitteleuropäischer Gehölzrinden. Pp. 193-367. - In H. Freund (ed). Handbuch der Mikroskopie in der Technik. Vol. 5,1. Umschau Verlag,
Frankfurt am Main.

Karsten, P. A. 1871: Mycologia fennica. Pars prima, Discomycetes. - Bidrag Känned. Finl. Nat. Folk. 19. 263 pp.

Kujala, V. 1946: Koivututkimuksia. - Comm. Inst. For. Fenn. 34,1. 36 pp.

—— 1964: Metsä- ja suokasvilajien levinneisyysja yleisyyssuhteista Suomessa. - Comm. Inst. For Fenn. 59,1. 137 pp. 196 maps.

Kurkela, T. 1973: Godronia multisporan aiheuttama tauti raudus- ja hieskoivun taimissa eräissä metsänlannoituskokeissa turvemaalla. - Suo 24: 8-15.

Mains, E. B. 1955: North American hyaline spored species of the Geoglossaceae. - Mycologia 47: 846-877.

- - 1956. North American speciès of the Geoglossaceae. Tribe Cudonieae. - Mycologia 48: 694-710.

Martineau, R. and Lavallee, A. 1971: Quebec region. - In Annual Report of the Forest Insect and Disease Survey, 1970. Can. For. Serv., Can. Dept. Fish. For., pp. 32-48.

Reнм, H. 1896: Ascomyceten: Hysteriaceen und Discomyceten. - Dr. L. Rabenhorst's Kryptogamenflora von Deutschland, Oesterreich und der Schweiz. 1,3. Verlag von Eduar Kummer, Leipzig. 1275 pp.

- - 1912: Zur Kenntnis der Discomyceten Deutschlands, Oesterreichs und der Schweiz. - Ber. Bayer. Bot. Ges. 13: 102-206.

SARvas, R. 1948: Tutkimuksia koivun uudistumisesta Etelä-Suomessa. — Comm. Inst. For. Fenn. 35,4. 91 pp.

—— 1949: Puumaiset koivulajimme. - Metsätal. Aikak. 1949: 9-13.

SGHLÄPFER-BERNHARD, E. 1968: Beitrag zur Kenntnis der Discomycetengattungen Godronia, Ascocalyx, Neogodronia und Encoeliopsis. - Sydowia. Ann. Myc. 22: 1-56.

Seaver, F. J. 1945: Photographs and descriptions of cup-fungi, XXXIX. - Mycologia 37: $333-359$.

Shear, L. C., Stevens, N. E., and Barn, H. F. 
1931: Fungous diseases of the cultivated cranberry. - U.S. Dept. Agr. Tech. Bull. 258. 57 pp.

Smerlis, E. 1968: The occurrence of forms of Godronia occurring in Quebec. - Can. J. Bot. 46: 597-599.

$\longrightarrow$ - 1969: Pathogenicity of some species of Godronia occurring in Quebec. - Pl. Dis. Rep. 53: $807-810$.
Sorauer, P. 1907: Blitzspuren und Frostspuren. Ber. Deutsch. Bot. Ges. 25: 157-164.

Weingartner, D. P. and Klos, E. J. 1969: Seasonal infection and sites of infection by Godronia cassandrae $\mathrm{f}$. vaccinii. - Phytopathology 59: 1056.

WRIGHT, E. 1933: A cork-borer method for inoculating trees. - Phytopathology 23: 487488. 